\title{
Catastrophic superior vena caval thrombus with massive pulmonary thromboembolism
}

\author{
G Vivek, ${ }^{1}$ Tom Devasia, ${ }^{1}$ Lorraine Simone Dias ${ }^{2}$
}

${ }^{1}$ Department of Cardiology, Kasturba Medical College, Manipal, Karnataka, India;

${ }^{2}$ Department of Internal Medicine, Kasturba Medical College, Manipal, Karnataka, India

Correspondence to G Vivek, vivekgraman@gmail.com

\section{DESCRIPTION}

A 60-year-old woman with no pre-existing illness was admitted with complaints of progressive dyspnoea of 3 days duration. On evaluation, the patient was orthopneic with significant tachycardia. Electrocardiogram showed sinus tachycardia and right axis deviation with S1O3T3 pattern. Transthoracic echocardiography revealed right heart chambers' enlargement with right ventricular dysfunction.
d-Dimer and troponin-T were positive. NT-ProBNP levels were elevated. Contrast CT of chest showed filling defects suggestive of acute thrombosis in the superior vena cava (figures 1 and 2, arrows), right pulmonary artery bifurcation (figure 3 , arrows show a saddle thrombus) and left middle and lower lobar arteries (figure 4). The patient died $1 \mathrm{~h}$ after the initiation of treatment with thrombolytic, inotropic agents and artificial ventilation.

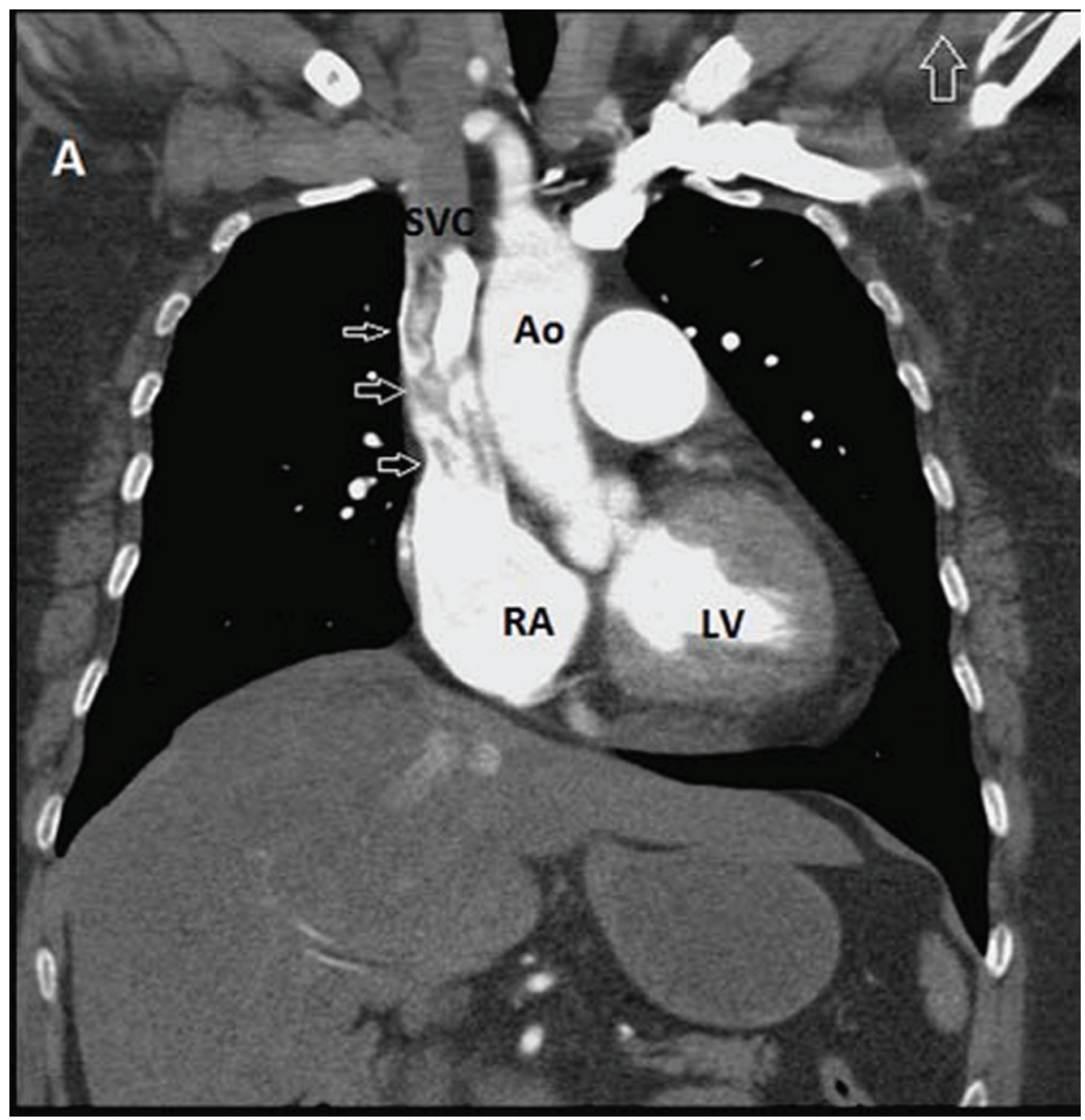

Figure 1 Contrast CT of chest showed filling defects (arrows) suggestive of acute thrombosis in the superior vena cava. Ao, aorta; SVC, superior vena cava; $R A$, right atrium; $L V$, left ventricle. 


\section{BMJ Case Reports}

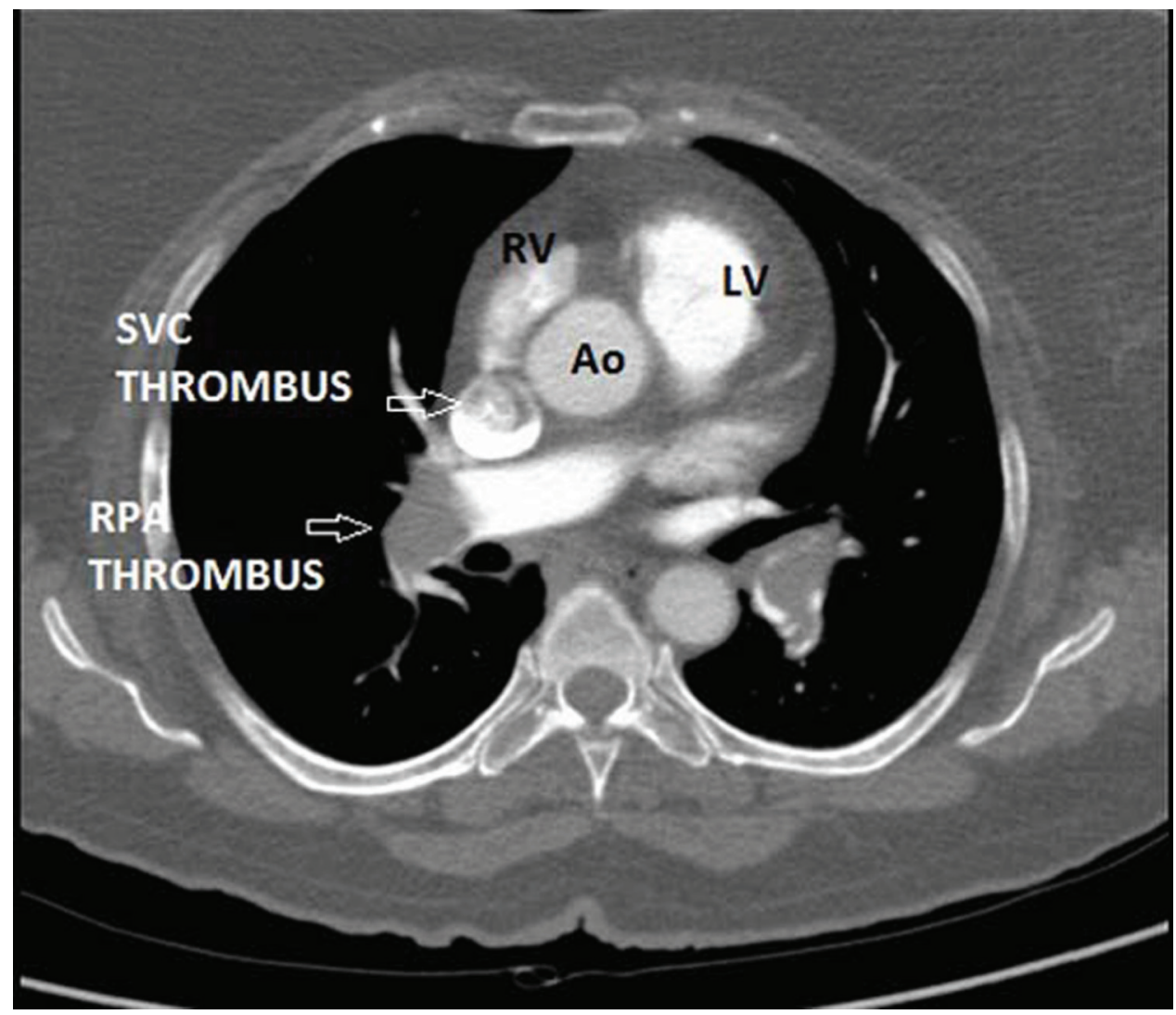

Figure 2 Contrast CT of chest showed filling defects suggestive of acute thrombosis in the superior vena cava and right pulmonary artery bifurcation. Arrows show a saddle thrombus. RPA, right pulmonary artery; Ao, aorta; SVC, superior vena cava; LV, left ventricle; RV, right ventricle.

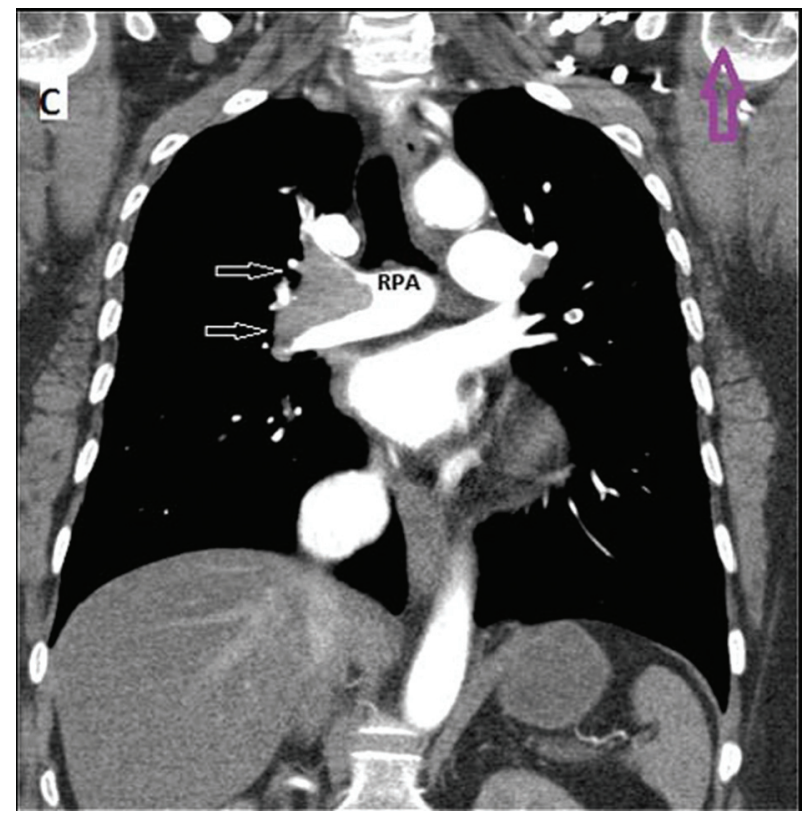

Figure 3 Contrast CT of chest showed filling defects suggestive of acute thrombosis in the right pulmonary artery bifurcation. Arrows show a saddle thrombus. RPA, right pulmonary artery.

Competing interests None.

Patient consent Obtained

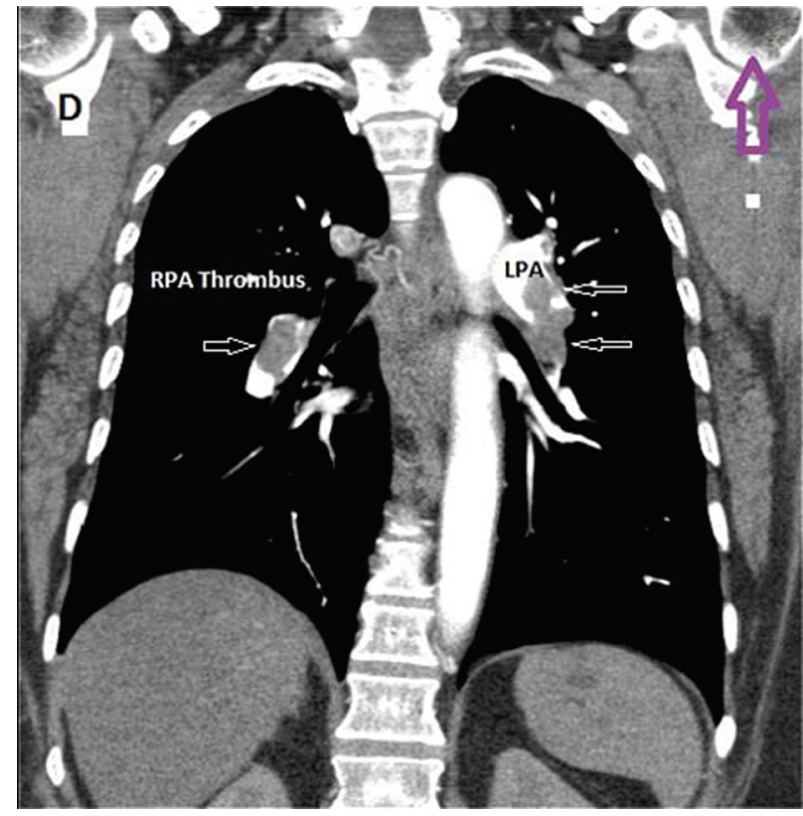

Figure 4 Contrast CT of chest showed filling defects (arrows) suggestive of acute thrombosis in the left middle and lower lobar arteries. RPA, right pulmonary artery; LPA, left pulmonary artery.

\section{REFERENCES}

1. Otten TR, Stein PD, Patel KC, et al. Thromboembolic disease involving the superior vena cava and brachiocephalic veins. Chest 2003;123:809-12. 
This pdf has been created automatically from the final edited text and images.

Copyright 2011 BMJ Publishing Group. All rights reserved. For permission to reuse any of this content visit http://group.bmj.com/group/rights-licensing/permissions.

BMJ Case Report Fellows may re-use this article for personal use and teaching without any further permission.

Please cite this article as follows (you will need to access the article online to obtain the date of publication).

Vivek G, Devasia T, Dias LS. Catastrophic superior vena caval thrombus with massive pulmonary thromboembolism. BMJ Case Reports 2011;10.1136/bcr.02.2011.3901, date of publication

Become a Fellow of BMJ Case Reports today and you can:

- Submit as many cases as you like

- Enjoy fast sympathetic peer review and rapid publication of accepted articles

- Access all the published articles

- Re-use any of the published material for personal use and teaching without further permission

For information on Institutional Fellowships contact consortiasales@bmjgroup.com

Visit casereports.bmj.com for more articles like this and to become a Fellow 